\title{
Community Empowerment in the Context of Sustainable Tourism Development in Surodadi Village
}

\author{
Syahrul Akbar ${ }^{*}$, Evi Noviyanti², Ute Lies Siti Khadijah ${ }^{3}$, Reiza D. Deinaputra ${ }^{4}$ \\ 1234 Master of Sustainable Tourism Study Program, Graduate School, \\ Universitas Padjajaran, Bandung, Indonesia \\ *Corresponding author. Email: syahrul19oo1@mail.unpad.ac.id, Phone: +6281353629603 \\ Received: 28 August 2020; Revised: 04 February 2021; Accepted: 29 Maret 2021
}

\begin{abstract}
The purpose of this study was to identify factual and potential conditions, as well as to analyze community empowerment in the tourism sector in Surodadi Village. This research used the descriptive qualitative research method. Data were collected through field observations, literature study, and documentation. The data were then analyzed using an interactive data analysis model, including data condensation, data presentation, and drawing conclusions. Furthermore, the factual conditions, tourism potential, and community empowerment in Surodadi Village were analyzed using five dimensions of the community-based tourism approach. The results showed that there are three pillars in the development of tourism in Surodadi Village, namely the economic, environmental, and social pillars. This study also recommends four stages in the development of community-based tourism in Surodadi Village, namely by assessing the needs and readiness of the community for tourism, training and preparing the community in the field of tourism, identifying and determining local leadership, and preparing and developing community organizations.
\end{abstract}

Keywords: community empowerment, community-based tourism, sustainable tourism, pro-poor tourism, community welfare

How to Cite: Akbar, S., Evi, N., Ute, L.S.K., \& Reiza, D.D. (2021). Community Empowerment in the Context of Sustainable Tourism Development in Surodadi Village. JPPM (Jurnal Pendidikan dan Pemberdayaan Masyarakat), 8(2), 131-146.

doi: 10.21831/jppm.v8i2.39164

\section{Introduction}

Tourism is a sector that serves as the backbone of the economy, especially in tourist destination regions. Tourism development that focuses on the sustainability of environment and local culture in the destination contributes to the efforts of cultural preservation and natural resource conservation that ultimately are the two main elements in tourism development. Based on this view, tourism development is considered as one of the sectors that can improve the life quality of the local community by reducing the poverty rate in a region (Luo \& Bao, 2019).

In 2019, the contribution of the tourism sector from the Hospitality and Food and Beverage Businesses to the Gross Regional Domestic Product (GRDP) at current prices according to businesses in Demak Regency was recorded at IDR $567 \mathrm{M}$ or $2.17 \%$ of the total GRDP of Demak Regency (Statistics Indonesia, 2020). The GRDP data shows the economic condition of a region, which indicates the ability of Demak Regency to manage or utilize resources in the tourism sector for the community. The higher the GRDP value of an area, the higher the income (Rahman \& Chamelia, 2015). 
JPPM (Jurnal Pendidikan dan Pemberdayaan Masyarakat), 8 (2), 2021 - 132

Syahrul Akbar, Evi Noviyanti, Ute Lies Siti Khadijah, Reiza D. Deinaputra

The economic motives to improve the economy of a region makes tourism one of the fastest growing industries in the world (Jamal \& Budke, 2020). Likewise in Indonesia, tourism is one of the sectors that continues to develop, as marked by the positive growth in foreign and domestic tourist travel (Nurhasanah, Alvi, \& Persada, 2017). However, efforts to reduce or eradicate poverty in underdeveloped villages through pro-poor tourism programs are still very limited.

In line with that, there are still few studies done on the subject of improving the community welfare in underdeveloped villages through the tourism sector. Herdiana (2019) analyzed the importance of community involvement in the development of tourist villages. The results formulate the roles of the community into two, namely as subjects who determine the direction of the tourism village development, as well as objects to improve the community welfare which is the priority of a tourism village development.

Further, a study done to analyze changes in the community due to tourism development found the negative impact of tourism development on the social aspects in rural communities, including the presence of social envy due to social inequality (Rofiq, 2017). Without a good management, there will be a potential conflict which can hinder the achievement of the goals of development in the tourism village.

Another study analyzed the obstacles in political participation, including low democratic and legal awareness in the community, as well as the community's limited economic participation on a small scale and at the basic work level. The findings of this study highlight the importance of self-awareness among the community to participate in tourism development based on a community participation theory which states that economic participation through political empowerment requires a considerable amount of time ( $\mathrm{Li}, 2017)$.

Moreover, research done on public participation in the Langkawi Island in Malaysia shows that there are limitations in public participation in the planning process of tourism development, which consist of four aspects, i.e. inadequate information, ineffective approaches, attitudes of the residents, and exclusion in the participation process. Public participation also only occurs at an early stage due to structural and operational constraints in the planning process (Marzuki, Hay, \& James, 2013).

Another study on the role of public participation in tourism development projects shows that tourism project development activities in Himalayan Ski Village involve the community only in the form of surfing training. Meanwhile, in the decisionmaking process related to the project, the community was not involved at all (Sherpa, 2011). The study of marine education based on community empowerment conducted by Marzaman in the Olele Marine Park, Bone Bolango Regency, Gorontalo Province (Marzaman \& Rasyid, 2020) found that the Olele Marine Park had great tourism potential in terms of the diversity of marine life. Challenges found in the management of marine parks were infrastructure and the capacity of human resources. In addition, there was no harmony between stakeholders (government, tourism industry players, and the Olele village community). The Olele Village also did not benefit economically as a result of competition with tourism businesses.

Other challenges in the empowerment of rural communities are the low level of community participation (Muarifuddin, 2017; Putridiani \& Suryono, 2019), limited access to capital or funding, the weak function of village institutions, and the high level of dependence on donor agencies (Muarifuddin, 2017). In addition, the low interest among 
JPPM (Jurnal Pendidikan dan Pemberdayaan Masyarakat), 8 (2), 2021 - 133

Syahrul Akbar, Evi Noviyanti, Ute Lies Siti Khadijah, Reiza D. Deinaputra

the community, especially the younger generation, to preserve Batik crafts and weaving as the community's social capital (Muarifuddin, 2017) (Putridiani \& Suryono, 2019) also hinders the community empowerment process. On the other hand, research in Sekapuk Village shows that community participation in a community-based tourism development can be increased through community involvement since the beginning of the planning and developing a mechanism for capital participation in village development (Asmoro, Yusrizal, \& Saputra, 2021). These two things can not only increase community participation, but also encourage community empowerment to be more significant.

In addition to studies conducted on community empowerment, a lot of research has also been done on the impact of tourism on poverty alleviation and the welfare improvement of communities in tourist destination areas. More specifically, one of the studies analyzes the impact of tourism on the livelihood of the poor, and how to increase the positive impacts of tourism for the low-income families. The findings show that poverty alleviation is not yet one of the goals of tourism development, as tourism development implemented by the government tends to use the economic, environmental, and cultural perspectives in the national and international levels (Ashley, Boyd, \& Goodwin, 200o). This study calculates the level of relevance of tourism in the poverty agenda, as well as the factors that create barriers to the economic participation of the poor in the tourism industry. Therefore, the discussion is emphasized on the strategies for promoting pro-poor tourism programs.

Another study identifies the impact of tourism development on the living conditions of the poor and analyzes the role of government and key investors in the tourism development process. The study finds that because local governments use a development approach, and investors follow the market logic in tourism development, the interests of the poor are then sacrificed for tourism development (Luo \& Bao, 2019). A study conducted by Truong, Hall and Garry in 2014 in Sapa, Vietnam has the closest research topic to the current study. This study analyzes the perceptions and experiences of the poor in Sapa, Vietnam related to tourism being used as a means for poverty alleviation. The findings of this study indicate that by taking into account the perspective of people experiencing poverty, the approach used in tourism development can serve better and more likely to succeed in alleviating poverty (Truong, Hall, \& Garry, 2014). However, the focus of this research is the perception of the poor on their role in tourism development. Another study discussed the perceptions of both tourists and local residents on the components of tourist destinations such as amenities, accessibility, and human resources (Listyowati, 2020). This study was conducted to determine the internal and external factors at Diamond Beach in order to develop a tourism development strategy, including product and service development, and market penetration.

Based on the background, this study was conducted with the objective of identifying the factual conditions of tourism potential and analyzing community empowerment in the tourism sector at Surodadi Village. The identification of tourism potential and the analysis on community empowerment are carried out using the fivedimension approach in community-based tourism, which includes economy, social aspect, culture, environment, and politics. The five dimensions will determine how the concept of sustainable tourism can be applied. 
JPPM (Jurnal Pendidikan dan Pemberdayaan Masyarakat), 8 (2), 2021 - 134

Syahrul Akbar, Evi Noviyanti, Ute Lies Siti Khadijah, Reiza D. Deinaputra

\section{Method}

This study used the qualitative research method, which refers to the type of research that seeks to analyze social issues and problems based on the point of view or interpretation of individuals in a natural setting (Creswell, 2014). Meanwhile, based on the purpose, this study can be classified as descriptive research (Sudaryono, 2018). In this case, the purpose of this study was to describe the factual conditions, tourism potential, and community empowerment in the tourism sector in Surodadi Village as it is without any intervention. In this study, the researcher acts as a key instrument. Data collection techniques included field observations, literature study, and documentation. Data analysis was conducted using the interactive data analysis approach (Miles, Huberman, \& Saldana, 2014), which includes several stages, namely data condensation, data presentation, and drawing conclusions. Furthermore, the community potential and empowerment in Surodadi Village were analyzed using 5 (five) dimensions in the community-based tourism approach, namely economic, social, cultural, environmental, and political dimensions.

\section{Community-based Tourism}

\section{Result and Discussion}

The role of the community in tourism development is introduced through the concept of Community-based Tourism (CBT). The term CBT first appeared in the mid1990 as the antithesis of tourism development which was perceived to only cause negative impacts on local communities as a result of economically-driven tourism developments (Asker, Boronyak, Carrard, \& Paddon, 2010; Nurhasanah et al. al., 2017; Suansri, 2003). Too much attention to the economic aspects of tourism causes the cultural, social and environmental values of the local community receive less proportional attention (Nurhasanah et al., 2017).

Based on the dynamics of the tourism development concept, community-based tourism is not present as a concept that will answer the question of how local communities benefit from tourism, but rather to answer the question of how tourism contributes to the local community development process (Suansri, 2003). Therefore, the definition of community-based tourism can be formulated as an effort to direct the development of tourism that preserves the cultural heritage of local communities as well as the natural environment while simultaneously improving the socio-economic welfare of local communities (Asker et al., 2010). Community-based tourism (CBT) can serve as a powerful means for community development and environmental conservation, especially when tourism and community development are seen as interconnected sectors. There are 5 (five) dimensions for implementing community empowerment through community-based tourism, as shown in Figure 1 below. 


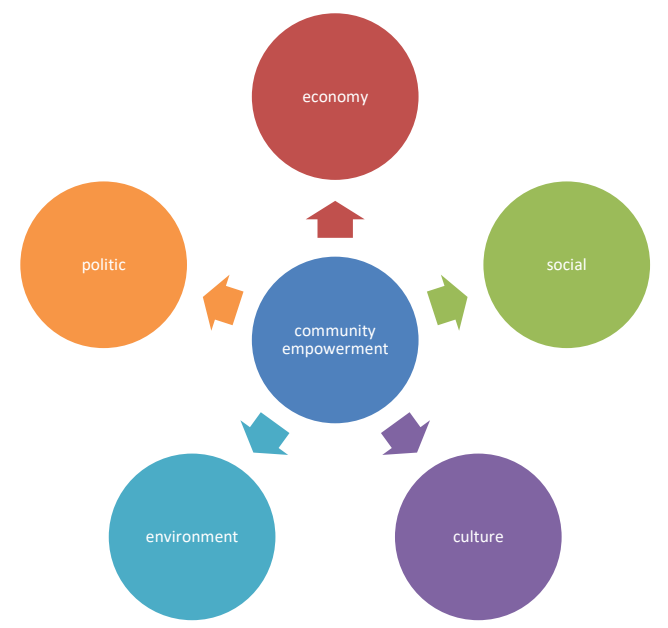

Figure 1. CBT Implementation as a Means for Community Empowerment (Suansri, 2013)

The figure shows the five dimensions of community-based tourism development which can be applied to the concept of sustainable tourism. From the economic perspective, the benefits of community empowerment in tourism development include creating more jobs in the tourism sector and increasing the income of local communities. These economic benefits can ultimately be obtained collectively and utilized for the local community development.

The positive impact in the economic dimension ultimately brings a positive impact in the social dimension of the community because economic independence leads to not only the quality of life but also the communal pride of the local community. In addition, there is a fair division of roles between men and women, the old and young generations, as well as the spirit to build and strengthen community organizations. Moreover, from the cultural point of view, CBT can encourage people to respect different cultures, help develop cultural exchanges, and instill the spirit of development in the culture of local community. The positive development of the cultural dimension in the local community will positively impact the development of the environmental dimension around the local community. The community can learn about the supporting capacities of the area, regulating waste disposal, and increasing the awareness of environmental conservation.

Based on the political dimension, community-based tourism can provide opportunities for increased local community participation, increased local community independence against external intervention, and guarantee the rights of local communities to manage their own natural resources. Internationally, the concept of community-based tourism is known by other terms. In Latin America, for example, the concept of "rural tourism" is applied in conjunction with CBT, and in some parts of Asia, the term "ecotourism" through CBT is more known. Regardless the term-sustainable tourism, community-based tourism, rural tourism or ecotourism-these concepts serve the same purpose (Asker et al., 2010).

\section{Sustainable Tourism}

The term sustainable tourism first emerged in the early 1990's as a result of the expansion of sustainable development discourse which was first introduced in 1973 and reached its momentum in 1980 (Mariani, Czakon, Buhalis, \& Vitouladiti, 2016; Weaver, 2006). The concept of sustainable development is defined as development that meets 
JPPM (Jurnal Pendidikan dan Pemberdayaan Masyarakat), 8 (2), 2021 - 136

Syahrul Akbar, Evi Noviyanti, Ute Lies Siti Khadijah, Reiza D. Deinaputra

the needs of the present without compromising the ability of future generations to meet their own needs (UNWTO \& United Nations Development Programme, 2017).

The idea of sustainable development is then applied to the tourism sector, which aims to utilize resources wisely while simultaneously conducting conservations actively to maintain the sustainability of resources in the long term (Yazdi, 2012). Essentially, sustainable tourism seeks to minimize negative impacts and maximize positive impacts on resource use (Weaver, 2006).

The three aspects of sustainable tourism are the environmental aspect (both natural and artificial), economic aspect (community and tourism industry), and social aspect (related to the impacts of tourism on the local culture, as well as on both local residents and tourists, including the way people who work in tourism are treated). Therefore, it is imperative that sustainable tourism: 1) make optimal use of environmental resources which serve as the key elements in tourism development, in addition to maintaining important ecological processes and helping to conserve natural resources and biodiversity; 2) respect the socio-cultural authenticity of the local community, preserve the cultural heritage and traditional values that have been built and preserved, and contribute to intercultural understanding and tolerance; and 3) ensure long-term viable economic operations, as well as provide equitable distribution of socio-economic benefits to all stakeholders, including stable employment and income-generating opportunities and social services for local communities, and contribute to poverty alleviation (UNWTO \& UNEP, 2005).

To minimize the negative impact of tourism on the environment and society, as well as maximize the positive and creative contributions of tourism to the local economy, conservation of natural and cultural heritage, as well as the quality of life of local communities and tourists, there are 12 points of agenda formulated to ensure sustainable tourism development. The 12 points in the agenda includes Economic Feasibility, Local Prosperity, Quality of Work, Social Justice, Visitor Satisfaction, Local Control, Community Welfare, Cultural Property, Physical Integrity, Biodiversity, Resource Efficiency, and Environmental Purity (Mowforth \& Munt, 2016; Sharpley, 2009; UNWTO \& UNEP, 2005).

The relationship between the 12 points of tourism agenda and the 3 pillars of sustainable tourism can be seen in the following figure.

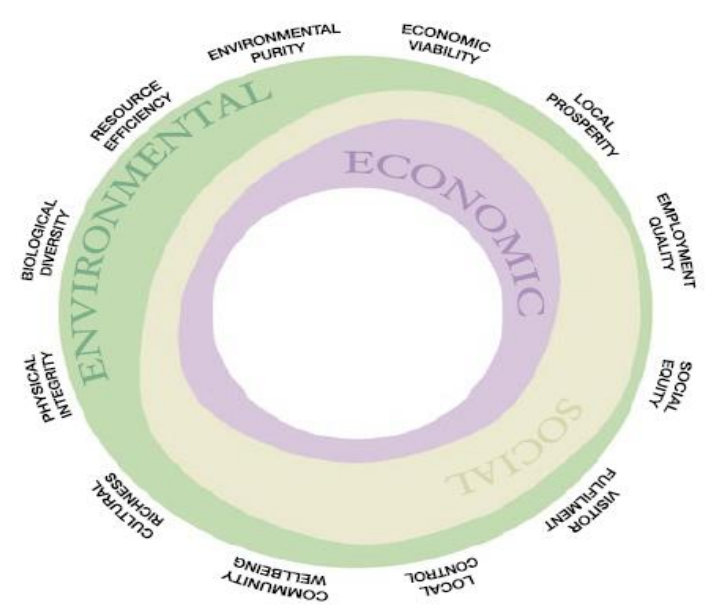

Figure 2. The Relationship Between the 12 Points of Tourism Agenda and the 3 Pillars of Sustainable Tourism 
JPPM (Jurnal Pendidikan dan Pemberdayaan Masyarakat), 8 (2), 2021 - 137

Syahrul Akbar, Evi Noviyanti, Ute Lies Siti Khadijah, Reiza D. Deinaputra

The sustainable tourism agenda shown in Figure $\mathbf{2}$ is not only related to one pillar but a combination of several pillars. For example, the customer satisfaction is an effort to meet the needs of the visitors and create opportunities, which is not only related to the social aspect, but also has an important role for the continuity of the economy.

\section{The Factual Condition of Surodadi Village}

Surodadi Village is located on the North Coast of Java Island, one of the villages in Sayung District, Demak Regency, Central Java Province. Surodadi Village consists of four hamlets, namely Surodadi Hamlet, Deling Hamlet, Gandong Hamlet and Baru Hamlet. The administrative territory of Surodadi Village spans to the north in the Java Sea, to the east bordering Tambakbulusan Village, to the south bordering the Banjarsari and Tugu villages, and to the west bordering Timbulsloko Village. Surodadi Village has an area of 568.5 hectares, which consists of settlements, fields/gardens, ponds, and others (rivers, mangrove forests, etc.).

Table 1. Land Use of the Surodadi Village

\begin{tabular}{clcc}
\hline No & \multicolumn{1}{c}{ Land Use } & Area (Ha) & Percentage (\%) \\
\hline 1 & Ricefield Land: Simple & - & - \\
2 & Kicerieid Land: Kain Keserve & - & - \\
3 & Yards/Buildings & 12.0 & 2.11 \\
4 & Fields/gardens & 4.5 & 0.79 \\
5 & Ponds & 543.0 & 95.51 \\
6 & Others (rivers, mangrove forests, etc.) & 9.0 & 1.58 \\
& Total & 568.5 & \\
\hline
\end{tabular}

Source: Surodadi Village Monography, 2019

Based on the data in Table 1 above, the majority of land uses in Surodadi Village are ponds (95.51\%), followed by yards/buildings (2.11\%), rivers and mangroves $(1.58 \%)$ and fields/gardens (0.79\%). Surodadi Village is located in a flat coastal area with an altitude of o-3 meters above sea level, an average air temperature of $300 \mathrm{C}$ and a tropical climate. In June-September the wind current comes from Australia and does not contain much water vapor, resulting in a dry season, whereas in December-March the wind brings water vapor from Asia and the Pacific Ocean, resulting in the rainy season.

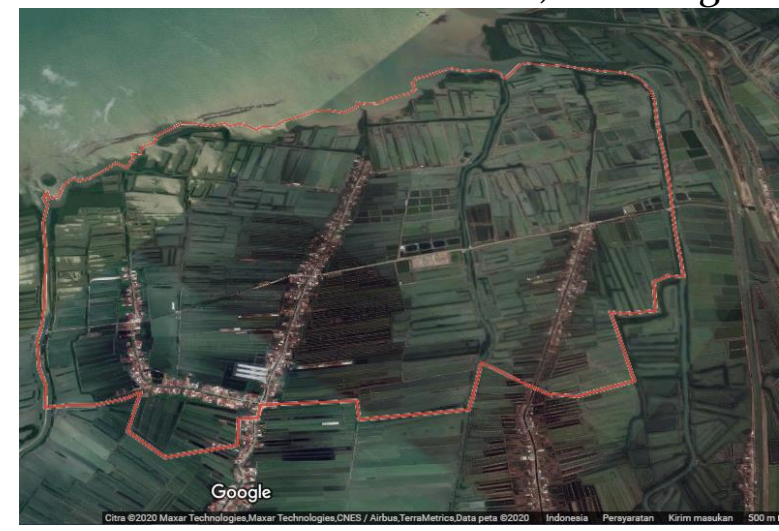

Figure 3. Surodadi Village Map

Source: Google Maps

Surodadi Village has a population of 2,993 people, consisting of 1,531 male residents and 1,462 female residents. The top three occupations in the Surodadi Village 
JPPM (Jurnal Pendidikan dan Pemberdayaan Masyarakat), 8 (2), 2021 - 138

Syahrul Akbar, Evi Noviyanti, Ute Lies Siti Khadijah, Reiza D. Deinaputra

community are pond farmers $(50.31 \%)$, pond farm laborers $(17.32 \%)$, and fishermen (11.93\%). The occupations of the people of Surodadi Village can be seen in Table 2. Meanwhile, the education background of the people in Surodadi Village is mostly only up to junior high school level (28.87\%), elementary school (22.85\%), high school (20.66\%), no education (11.11\%), and college (1.97\%).

Table 2. Occupations of the Surodadi Village Community

\begin{tabular}{clcc}
\hline No. & \multicolumn{1}{c}{ Occupation } & $\begin{array}{c}\text { Number of } \\
\text { People }\end{array}$ & Percentage (\%) \\
\hline 1 & Pond farmers & 485 & 50.31 \\
2 & Pond farm laborers & 167 & 17.32 \\
3 & Fishermen & 115 & 11.93 \\
4 & Industrial Workers & 76 & 7.88 \\
5 & Sellers & 45 & 4.67 \\
6 & Construction Workers & 27 & 2.80 \\
7 & Government Employee & 7 & \\
& (Public & & 0.73 \\
8 & Servant/Military/Police) & & 0.41 \\
9 & Transport Services & 4 & 0.21 \\
10 & Business Owners & 2 & 0.21 \\
11 & Others & 2 & 3.53 \\
& Total & 34 & 100.00 \\
\hline
\end{tabular}

Source: Surodadi Village Monography, 2019

The high rate of residents with elementary and junior high school education background may be caused by the lack of awareness on the importance of education for children. In addition, most of the residents still assumed that even if the children pursued education, they would eventually return and manage the pond to continue their family's business and make a living by becoming fishermen (Cahyaningrum \& Setyowati, 2016). Another factor that plays a role in the low education background in Surodadi Village is the availability of proper education facilities at the elementary school level.

Based on the 2019 Developing Village Index issued by the Ministry of Villages, Villages, Development of Disadvantaged Regions and Transmigration, Surodadi Village in the Sayung District still belongs in the disadvantaged village category (http://idm.kemendesa.go.id//idm_data). A disadvantaged village or also known as PraMadya is a village with social, economic, and ecological potential that has not been optimally managed in the efforts of improving the village community welfare and life quality, and experiences poverty in various forms as a result. The data was obtained based on assessments on the four dimensions of the Developing Village Index, namely the social aspect, health, education, and the residential social capital, including economic resilience, ecology, and village potential.

\section{Issues in Surodadi Village}

Due to its location on the north coast of Java Island, Surodadi Village has experienced changes in the coastline in the form of accretion and abrasion. The coastal area of Surodadi Village used to have an initial beach length of $4,023.75 \mathrm{~m}$ and has experienced abrasion of 1.197 ha, and accretion (land extension) of 0.49 ha in 2016 (Riyanti, Suryanto, \& Ain, 2017). The west monsoon between November - February results in strong currents and big waves, which leads to abrasion on the ponds and 
JPPM (Jurnal Pendidikan dan Pemberdayaan Masyarakat), 8 (2), 2021 - 139

Syahrul Akbar, Evi Noviyanti, Ute Lies Siti Khadijah, Reiza D. Deinaputra

mangroves, whereas the accretion is a result of the east monsoon between March October.

Another factor that contributes to the abrasion and accretion process at the Surodadi beach is the declining area of the mangrove forest which is increasingly converted into ponds and residential area around the beach (Cahyaningrum \& Setyowati, 2016; Riyanti et al., 2017). The harbor development in Semarang also affects abrasion because the construction materials carried by the ocean currents are held up along the concrete dams built to calm the incoming currents. As a result, there is silting in the waters of the port which causes severe abrasion on the surrounding area, including on the coast of Surodadi Village (Cahyaningrum \& Setyowati, 2016). Due to unresolved abrasion, ponds and the land area of the village are in danger of being damaged. In order to avoid abrasion on ponds on the coast, the residents prefer to build the ponds around the residential area.

In addition to abrasion and accretion, the village is often affected by tidal waves. This is because the Sayung District has a relatively flat topography and located about 3 meters above sea level. Due to such natural condition, when the sea level is rising, the Surodadi village area has a risk for flooding or inundation. The flooded area in the Sayung District is larger during the west monsoon compared to the east monsoon, as illustrated in Figure 4 and 5.

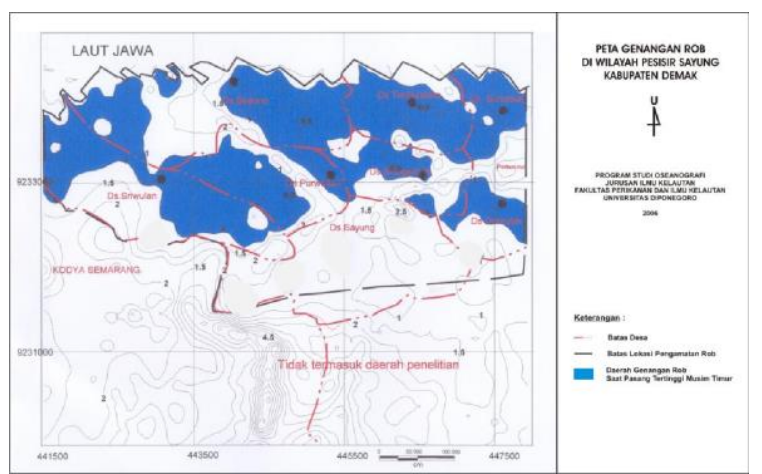

Figure 4. Map of Flooded Area during the East Monsoon

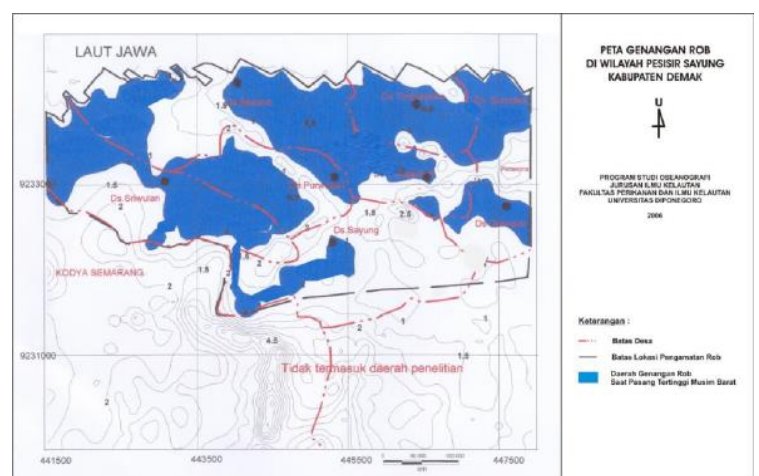

Figure 5. Map of Flooded Area during the West Monsoon Source: (Widada, Rochaddi, \& Endrawati, 2017)

The tidal inundation that happens to most of the area of the village is due to the location of the village which is directly adjacent to the sea, with no barriers or banks. 
JPPM (Jurnal Pendidikan dan Pemberdayaan Masyarakat), 8 (2), 2021 - 140

Syahrul Akbar, Evi Noviyanti, Ute Lies Siti Khadijah, Reiza D. Deinaputra

Moreover, the land used for ponds on the left and right side of the river mouth area experiences abrasion and becomes the entrance for sea water to flood the village.

The tidal inundation has resulted in the loss of 24 residential units between 20092013 (Asiyah, Rindarjono, \& Muryani, 2016). In addition to decreasing the quality of the residential area, the flood also affects the building construction quality and the public facilities and infrastructure in the village. Inundation or flood can accelerate the aging process in buildings that not only damages the building, but also makes the surrounding settlement area less clean.

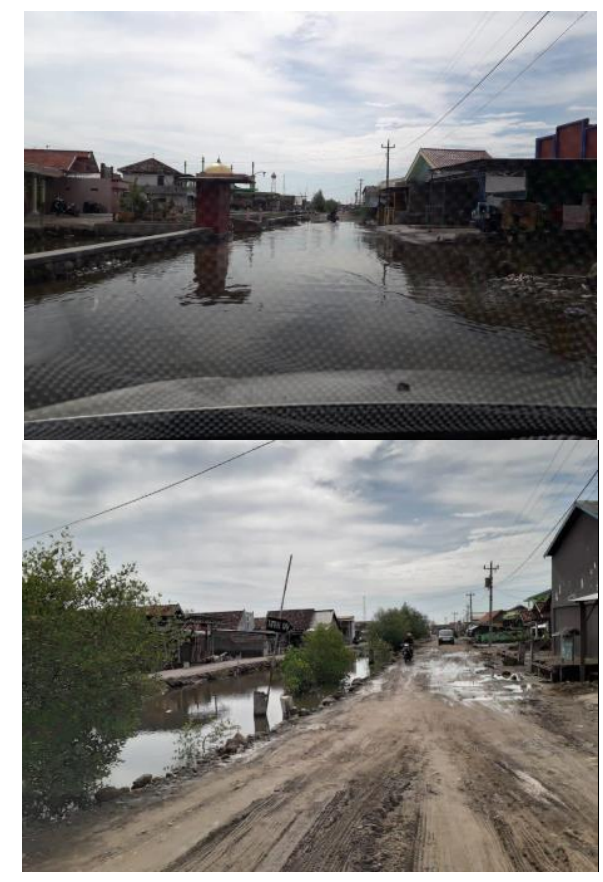

Figure 5. Street Condition Due to Tidal Inundation Source: Research Findings, 2020

At last, the village community has gotten used to the unfortunate natural incidents that impact the village from time to time. In order to survive, they have attempted various strategies, such as elevating the building, making rumah panggung (traditional elevated house built on stilts), elevating the beds, and even moving out of the region.

\section{The Potential of Surodadi Village}

As a result of abrasion, accretion and inundation in the Surodadi Village area, a collective awareness emerged among the community to rehabilitate the environment by planting mangroves along the coastline and the embankments of their ponds. This action is aimed to protect the area and their ponds from more severe abrasion. As a result, the condition of the mangroves in Surodadi Village has improved. Of the total mangrove area of 446 ha, 325 ha is in a good condition, 21 ha is in a damaged condition, and 100 ha is in a cultivation-ready condition. The number of mangrove trees in good condition has led to this village being awarded the national pond intensification award in 2004, and the best coastal reforestation at the national level in 2007 (Asiyah et al., 2016). 
JPPM (Jurnal Pendidikan dan Pemberdayaan Masyarakat), 8 (2), 2021 - 141

Syahrul Akbar, Evi Noviyanti, Ute Lies Siti Khadijah, Reiza D. Deinaputra

The success of Surodadi Village residents in rehabilitating and protecting the mangrove forest cannot be separated from the community participation in the making of village regulations to preserve the mangrove forest. The village regulations were drawn up through deliberations between the village government, farmers groups in Surodadi village, and the village representative body. In addition to the participatory process of drafting regulations, the substance or content of village regulations also benefits to the people of Surodadi Village, most of whom work as fishermen and pond farmers. The regulation protects the mangrove forest and the mangrove ecosystems which consist of the mangrove forest, living organisms that live in the mangrove forest, humans, and the supporting physical environment.

Although the mangrove forest has the potential to thrive in the tourism sector, it has not been fully developed, as indicated by the lack of the trail or walking path in the mangrove forest. Another site with the tourism potential in the village is the black sand beach covering an area of \pm 4 ha. The black sand beach is a result of accretion or change in the coastline to the ocean due to the sedimentation process from the land or river toward the ocean which occurs for years. The accumulation of sand sedimentation around the mangrove forest area adds to its attractiveness, creating a new tourist attraction. Initially, the site was a disappearing land due to abrasion since the 1990's. However, the accretion process began in 2017, creating a new beautiful extended area of the beach. The accumulation of sediment has created a coastal area of nearly 4 ha, and an additional $\mathbf{2}$ ha of mangrove forest that was previously flooded by sea water.

The beach in Surodadi Village was opened for the first time for tourist visits in early 2020. According to the Head of Surodadi Village, this beach will be managed as a village-owned enterprise which aims to improve the welfare of the people in Surodadi Village. To get to this beach, tourists must use a fishing boat available at the end of Surodadi Village along the river with views of the mangrove forest on the left and right of the river. The distance to the beach from the port is about $1 \mathrm{~km}$ and takes approximately 30 minutes. Some community groups that will benefit from this tourism development are groups of sellers and fishermen who rent out their boats.

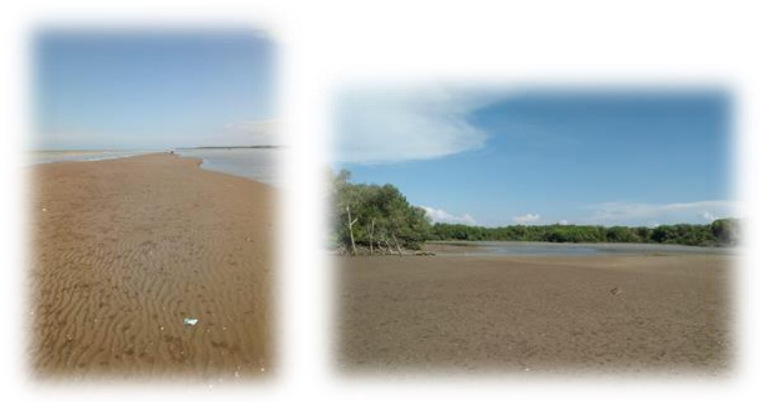

Figure 6. Surodadi Beach

Although it has been opened for tourist visits, both the mangrove forest area and Surodadi beach have not been developed optimally for tourism purposes.

\section{Continuous Tourism and Community-based Tourism in Surodadi Village}

Based on the discussion on the tourism potential in Surodadi Village, there are three aspects of sustainable tourism in the village, i.e.: 
JPPM (Jurnal Pendidikan dan Pemberdayaan Masyarakat), 8 (2), 2021 - 142

Syahrul Akbar, Evi Noviyanti, Ute Lies Siti Khadijah, Reiza D. Deinaputra

a) Economy: Tourism development in Surodadi Village will empower and improve the economy of the Surodadi Village community, because the tourist attractions are managed as village-owned enterprises. Based on the Regulation of the Minister of Villages, Development of Disadvantaged Regions, and Transmigration of the Republic of Indonesia Number 4 of 2015 concerning the Establishment, Administration, and Management, and Dissolution of Village-Owned Enterprises, village-owned enterprises are business entities whose entire or most of the capital is owned by the Village which is separated for the purpose of managing assets, services, and other businesses for the maximum welfare of the Village community. Villageowned enterprises are established with the aim of improving the village economy, optimizing village assets so that they have a value for village welfare, increasing community businesses in managing the village economic potential, developing business cooperation plans between villages or with third parties, creating market opportunities and networks which supports the needs of citizens' public services, creates employment opportunities, improves community welfare through improved public services and growth and equity of the village economy, as well as increasing the village community income and the village original income.

b) Environment: With the vulnerability of the Surodadi Village to natural disasters in the form of abrasion, accretion, and inundation, the community is left with one option, namely to continue and ensure environmental conservation in their village. The efforts made by the Surodadi Village community to maintain and protect environmental sustainability are through the development of Village Regulations regarding the preservation of the mangrove forest. The formulation of the village regulations is carried out through deliberations between the Village Government, the farmers groups in the Surodadi Village and the Village Representative Body. In addition to its participatory nature, the village regulations also accommodate the aspirations of the Surodadi Village community to ensure that the implementation of the village regulations is very effective in preserving and protecting the mangrove forest area in the village.

c) Social Aspect: Tourism development impacts the social aspects through community involvement in the tourism development process in Surodadi Village. Community involvement can be started from the process of planning, implementing, utilizing, maintaining, and evaluating tourism development in Surodadi Village. Community involvement in the tourism development process in Surodadi Village will create a sense of responsibility and a sense of belonging to the region.

In the development of community-based tourism, there are four steps that must be taken by the stakeholders, namely 1) assessing the needs and readiness of the community toward tourism, 2) training and preparing the community for tourism, 3) identifying and establishing local leadership, and 4) preparing and developing community organizations (Hamzah et al., 2009).

The first and most fundamental step in developing community-based tourism is by assessing the needs and preparedness of the community in regard to tourism development. This stage includes basic questions which must be addressed by the community before they are ready to undergo tourism development. These questions will help encourage the community to exchange their thoughts on why they must be involved in tourism development, and why tourism development must be done. Next, it 
is important to determine the role of tourism on the community life, for example, as an alternative livelihood or an additional source of income for the community, in addition to their jobs as pond farmers and fishermen. In addition, tourism may also serve as a means to justify the conservation efforts of the village environment, mainly because the village condition that is prone to disasters.

Tourism may serve as an alternative source of livelihood and resources as well as initial training for the community to be able to play a role in other economic sectors in the future. After determining the role of tourism, the next stage in the first step is to conduct a situational analysis which includes the community's expectations of the benefits derived from community-based tourism development, determining the values, positions, aspirations and concerns of the community, and identifying the tourism sector workforce.

The second step is to train and prepare the community in the tourism sector. In order to develop community-based tourism, there are a number of things that must be done in this step, including initial assessments of the tourism potential to be developed and promoted, building a network with other tourist attractions in the surrounding area, conducting special trainings for some community groups, identifying the training needs, and developing modules for further training. It is also important to do a study trip to other community-based tourist attractions or sites in order to set a benchmark in tourism development in the region. Lastly, the module training development must be done to ensure that the training is done in a systematic and consistent manner.

To ensure the sustainability of community-based tourism development in Surodadi Village is to identify and determine local leaders/winners. This is essential because the future of the developed tourism destinations will depend fully on the presence of strong leaders who are respected by the community. A strong leadership character can be adapted to the socio-cultural life of the local community, such as in the form of Village Heads, Religious Leaders, Traditional Leaders, Leaders of Youth Organizations or other figures who have sensitivity and concern for tourism development.

The final step that must be taken is to prepare and develop community organizations. Community organizations in tourism development in Indonesia are known as Tourism Awareness Group. This organization is important to accompany the life cycle process of tourism products that are developed in the early phase as well as in an established category. In the last phase, innovation interventions from leaders and organizations are needed to prevent tourism products from entering the decline phase. In addition, it is also necessary to identify the role of organizations in empowering women and youth, formulating a realistic vision, fostering an independent mentality (not depending on government assistance, etc.), and in managing community funds. In relation to this, the community funds are sourced from the percentage of income obtained from tourism activities and distributed for the socio-economic development of the local community. This scheme will be implemented through the Village Owned Enterprises in Surodadi Village.

\section{Conclusion}

Based on the discussion above, it can be concluded that there are three pillars of community-based tourism development in Surodadi Village. The first one is the economic aspect through the establishment of village-owned enterprises that manage 
JPPM (Jurnal Pendidikan dan Pemberdayaan Masyarakat), 8 (2), 2021 - 144

Syahrul Akbar, Evi Noviyanti, Ute Lies Siti Khadijah, Reiza D. Deinaputra

tourist destinations that aim to increase people's income in Surodadi Village. The second one is the environment aspect that is taken into account through village regulations to protect the mangrove forest by involving all components of the community in Surodadi Village, whereas the last one is the social aspect in the form of community involvement in tourism development in Surodadi Village starting from the planning, implementation, utilization, maintenance, up to the evaluation stage to develop community-based tourism in Surodadi Village. The combination of these three pillars shows that the tourism sector can be used to increase community empowerment.

Recommendations for relevant stakeholders, especially the village government, for the development of community-based tourism in Surodadi Village consist of four stages of development, namely: assessing the community's needs and readiness for tourism, training and preparing the community in the tourism sector, identifying and determining local leadership, and preparing and developing community organizations. Due to the limitations of this study, it is recommended that a case study be done on community-based tourism development strategies in Surodadi Village for the sustainability of tourism development in the village as an effort to assist and contribute scientifically to develop tourism potential in the village.

\section{References}

Ashley, C., Boyd, C., \& Goodwin, H. (200o). Pro-Poor Tourism : Putting Poverty At the Heart of the Tourism Agenda. Natural Resource Perpectives, 51(51), 1-6. Retrieved from http://www.odi.org.uk/resources/docs/2861.pdf

Asiyah, S., Rindarjono, M. G., \& Muryani, C. (2016). Analisis Perubahan Permukiman dan Karakteristik Permukiman Kumuh Akibat Abrasi dan Inundasi di Pesisir Kecamatan Sayung Kabupaten Demak Tahun 2003 - 2013. GeoEco, 2(2), 198-207.

Asker, S., Boronyak, L., Carrard, N., \& Paddon, M. (2010). Effective Community Based Tourism. In Apec Tourism Working Group.

Asmoro, A. Y., Yusrizal, F., \& Saputra, I. (2021). Pariwisata Berbasis Masyarakat di Desa Sekapuk: Sebuah Participatory Action Research. JPPM (Jurnal Pendidikan Dan Pemberdayaan Masyarakat), 8(1), 30-47. https://doi.org/https://doi.org/10.21831/jppm.v8i1.34144

BPS, B. P. S. K. D. (2020). Kabupaten Demak Dalam Angka Tahun 2017.

Cahyaningrum, D., \& Setyowati, E. (2016). Efektifitas Pelaksanaan Peraturan Desa dalam Menjaga Kelestarian Hutan Mangrove di Desa Surodadi, Kecamatan Sayung, Kabupaten Demak. Negara Hukum, 2(1), 29-50. Retrieved from http://jurnal.dpr.go.id/index.php/hukum/article/view/186

Creswell, J. W. (2014). Research Design: Qualitative, Quantitative, and Mixed Methods Approaches (Fourth Edi). California: SAGE Publications Ltd.

Demak, B. K. (2020). Kabupaten Demak Dalam Angka Tahun 2017.

Hamzah, A., Khalifah, Z., Ismail, H. N., Baharudin, N. H., Bhaskaran, L., \& Nooruddin, R. (2009). Handbook on Community Based Tourism "How to Develop and Sustain CBT." In APEC Tourism Working Group. https://doi.org/10.1108/WHATT-06-2015-0023

Herdiana, D. (2019). Peran Masyarakat Dalam Pengembangan Desa Wisata Berbasis Masyarakat. Jumpa, 6(1), 63-86.

Jamal, T., \& Budke, C. (2020). Tourism in a world with pandemics : local-global responsibility and action. https://doi.org/10.1108/JTF-02-2020-0014

Li, J. (2017). Public Participation in Tourism Development: An Analysis of Community Development in Underdevelopment Areas. DEStech Transactions on Environment, Energy and Earth Science, (apees). https://doi.org/10.12783/dteees/apees2017/7693

Listiowati, A. S. (2020). Strategi Pengembangan DTW Pantai Diamond di Dusun Pelilit, Desa Pejukutan, Nusa Penida, Klungkung, Bali. Jumpa, 6(Januari 2020), 516-540. 
JPPM (Jurnal Pendidikan dan Pemberdayaan Masyarakat), 8 (2), 2021 - 145

Syahrul Akbar, Evi Noviyanti, Ute Lies Siti Khadijah, Reiza D. Deinaputra

Luo, X., \& Bao, J. (2019). Exploring the impacts of tourism on the livelihoods of local poor: the role of local government and major investors. Journal of Sustainable Tourism, 27(3), 344359. https://doi.org/10.108o/o9669582.2019.1578362

Mariani, M. M., Czakon, W., Buhalis, D., \& Vitouladiti, O. (2016). Tourism Management, Marketing, and Development: Performance, Strategies, and Sustainability. In Tourism Management, Marketing, and Development (1st ed.). https://doi.org/10.1057/9781137354358

Mowforth, M., \& Munt, I. (2016). Tourism and Sustainability: Development, Globalisation and New Tourism in the Third World. In Tourism and Sustainability (4th ed.). https://doi.org/10.4324/9781315795348

Mariani, M. M., Czakon, W., Buhalis, D., \& Vitouladiti, O. (2016). Tourism Management, Marketing, and Development: Performance, Strategies, and Sustainability. In Tourism Management, Marketing, and Development (1st ed.). https://doi.org/10.1057/9781137354358

Marzaman, A., \& Rasyid, A. U. (2020). Eduwisata Bahari Berbasis Pemberdayaan Masyarakat dalam Pengembangan Taman Laut Olele, Kab. Bone Bolango, Provinsi Gorontalo. Jurnal Master Pariwisata (JUMPA), 6, 267. https://doi.org/10.24843/jumpa.2020.vo6.io2.po2

Marzuki, A., Hay, I., \& James, J. (2013). Public participation shortcomings in tourism planning: the case of the Langkawi Islands, Malaysia. Tourism Planning and Development, 10(4), 494512. https://doi.org/10.108o/21568316.2013.804432

Miles, M. B., Huberman, A. M., \& Saldana, J. (2014). Qualitative Data Analysis: a Methods Sourcebook. In SAGE Publication (Third Edit). Arizona: SAGE Publications Ltd.

Mowforth, M., \& Munt, I. (2016). Tourism and Sustainability: Development, Globalisation and New Tourism in the Third World. In Tourism and Sustainability (4th ed.). https://doi.org/10.4324/9781315795348

Muarifuddin, M. (2017). Implementasi pembangunan Desa Wisata Batik Desa Babagan Kecamatan Lasem Kabupaten Rembang. Jurnal Pendidikan Dan Pemberdayaan Masyarakat, 4(1), 51. https://doi.org/10.21831/jppm.v4i1.12713

Nurhasanah, I. S., Alvi, N. N., \& Persada, C. (2017). Perwujudan Pariwisata Berkelanjutan Melalui Pemberdayaan Masyarakat Lokal Di Pulau Pahawang, Pesawaran, Provinsi Lampung. Tataloka, 19(2), 117. https://doi.org/10.14710/tataloka.19.2.117-128

Putridiani, S. A., \& Suryono, Y. (2019). Pemberdayaan Pengrajin Tenun. JPPM (Jurnal Pendidikan Dan Pemberdayaan Masyarakat), 6(2), 161-169.

Rahman, Y. A., \& Chamelia, A. L. (2015). Faktor - Faktor Yang Mempengaruhi Pdrb Kabupaten / Kota Jawa Tengah Tahun 2008-2012. Jejak, 8(1), 88-99. https://doi.org/10.15294/jejak.v8i1.3857

Riyanti, A. H., Suryanto, A., \& Ain, C. (2017). Sayung dengan Menggunakan Citra Satelit Dynamics of Coastal Line Changes in the Surodadi Village of Sayung Sub District by Using Satellite Imagery. 6, 433-441.

Rofiq, A. (2017). Perubahan masyarakat Desa Wisata Bejiharjo pada tahun 2010-2015. Jurnal Pendidikan Dan Pemberdayaan Masyarakat, 4(1), 1. https://doi.org/10.21831/jppm.v4i1.10035

Sharpley, R. (2009). Tourism development and the environment: Beyond sustainability? In Tourism Development and the Environment: Beyond Sustainability? (1st ed.). https://doi.org/10.4324/9781849770255

Sherpa, Y. D. (2011). Public Participation In Tourism Development: A Case Study Of The Himalayan Ski Village (HSV) Project In Manali, India (Vol. 2). https://doi.org/10.5296/jpag.v8i3.13638

Sherpa, Y. D. (2011). Public Participation in Tourism Development: A case study of the Himalayan Ski Village (HSV) project in Manali, India (Vol. 2). https://doi.org/10.5296/jpag.v8i3.13638

Suansri, P. (2003). Community based tourism handbook.

Sudaryono. (2018). Metodologi Penelitian: Kuantitatif, Kualitatif dan Mix Method. In Rajawali 
JPPM (Jurnal Pendidikan dan Pemberdayaan Masyarakat), 8 (2), 2021 - 146

Syahrul Akbar, Evi Noviyanti, Ute Lies Siti Khadijah, Reiza D. Deinaputra

Pers (Edisi Kedu, Vol. 2). Jakarta: PT. Rajagrafindo Persada.

Sharpley, R. (2009). Tourism development and the environment: Beyond sustainability? In

Tourism Development and the Environment: Beyond Sustainability? (1st ed.). https://doi.org/10.4324/9781849770255

Suansri, P. (2003). Community Based Tourism Handbook.

Truong, V. D., Hall, C. M., \& Garry, T. (2014). Tourism and poverty alleviation: Perceptions and experiences of poor people in Sapa, Vietnam. Journal of Sustainable Tourism, 22(7), 10711089. https://doi.org/10.108o/o9669582.2013.871019

UNWTO, W. T. O., \& UNEP, U. N. E. P. (2005). Making Tourism More Sustainable: a Guide for Policy Makers. In G. Carbone, E. Yunis, R. Denman, \& G. Bird (Eds.), Journal of Chemical Information and Modeling. https://doi.org/10.1017/CBO9781107415324.004

UNWTO, W. T. O., \& United Nations Development Programme, U. (2017). Tourism and the Sustainable Development Goals - Journey to 203o. https://doi.org/10.18111/9789284419401

UNWTO, W. T. O., \& UNEP, U. N. E. P. (2005). Making Tourism More Sustainable: a Guide for Policy Makers. In G. Carbone, E. Yunis, R. Denman, \& G. Bird (Eds.), Journal of Chemical Information and Modeling. https://doi.org/10.1017/CBO9781107415324.004

UNWTO, W. T. O., \& United Nations Development Programme, U. (2017). Tourism and the Sustainable Development Goals - Journey to 2030. https://doi.org/10.18111/9789284419401

Weaver, D. (2006). Sustainable Tourism: Theory and Practice. Retrieved from http://repositorio.unan.edu.ni/2986/1/5624.pdf

Widada, S., Rochaddi, B., \& Endrawati, H. (2017). Pengaruh Arus terhadap Genangan Rob di Kecamatan Sayung Kabupaten Demak. Journal of Chemical Information and Modeling, 53(9), 1689-1699. https://doi.org/10.1017/CBO9781107415324.004

Yazdi, S. K. (2012). Sustainable Tourism. American International Journal of Social Science, 1(1), $50^{-} 55$. 